J. Asiat. Soc. Bangladesh, Sci. 39(1): 27-33, June 2013

\title{
IN VITRO CONTROL OF FIVE PATHOGENIC FUNGI ISOLATED FROM GROUNDNUT (ARACHIS HYPOGAEA L.)
}

\author{
SHAILA SHARMIN AND SHAMIM SHAMSI ${ }^{1}$ \\ Department of Botany, University of Dhaka, Dhaka-1000, Bangladesh
}

\begin{abstract}
Efficacy of five plant extracts namely, Allium cepa, Allium sativum, Azadirachta indica, Tagetes patula and Zingiber officinale was evaluated against five pathogenic species of fungi isolated from groundnut in vitro. These were Colletotrichum acutatum, Colletotrichum dematium, Colletotrichum orbiculare, Colletotrichum sp. and Fusarium semitectum. Colony growth of $C$. dematium was completely checked with Allium sativum at all the concentrations used $(5,10$ and $20 \%)$. Similarly $A$. cepa, A. sativum and $A$. indica completely inhibited the colony growth of $C$. orbiculare at the same concentrations used. T. patula and Z. officinale also showed appreciable inhibition in colony growth of five species of fungi at 10 and $20 \%$ concentrations.
\end{abstract}

Key words: In vitro, Control, Pathogenic fungi, Groundnut

\section{Introduction}

Groundnut, one of the principal economic crop of world occupies $13^{\text {th }}$ position among fruit crops (Varnell and Mccloud 1975), $4^{\text {th }}$ place among the oilseed crops in respect to both area and production next to soybean, sunflower and cotton (Weiss 1983). Groundnut is the second major oil crops in Bangladesh covering an area of 76 thousand ha. producing 1.2 million MT of nuts. Bangladesh produces 46000 MT of groundnut (BBS 2007). Increase in the production of this crop can help to minimize the shortage of edible oil in our country. It is the richest plant source of thiamin $\left(B_{1}\right)$. Groundnut contains at least 13 different types of vitamins and also rich in 26 essential minerals. Incidence of disease is the most important obstacle for groundnut production. Fungi can be rendered as the most harmful microorganism and so far, 46 fungal diseases were recorded on groundnut and 67 (aprox.) fungi were associated with various symptoms type (Wikipedia 2012). In Bangladesh, groundnut suffers from many diseases out of which 14 are fungal, two are viral, nine are nemic and one is mycoplasma disease (Ahmed 1985, Baker et al. 1980, Fakir 1980 and Talukder 1974). Shamsi and Sharmin (2012) recorded ten types of symptoms on eighteen varieties of groundnut during the period of December 2010 to May 2012. This investigation also revealed that a total of 48 species of fungi representing 24 genera was associated with 18 vareites of Arachis hypogaea. To protect groundnut from diseases, one must have knowledge on etiology of disease, isolation and identification of causal organism, prevention and control measure. Much research works have been carried out on management of diseases of groundnut in different parts of the

${ }^{1}$ Corresponding author: Email: prof.shamsi@gmail.com 
world (Ambang et. al. 2011, Sing et al. 1997 and Sunker et al. 2005). In Bangladesh very little work has been done to protect groundnut from the incidence of diseases (Mia et al. 2007, Bakr et al. 2009 and Sharmin 2012). Control of plant diseases by using plant extract having antifungal properties has recently gaining appreciable importance to plant pathologists. Intensive research has been done in this field to avoid the hazardous impact of pesticides and agro-chemicals on ecosystem. On account of their non phytotoxicity, biodegradability and renewable nature such substances appear to be the ideal antifungal agents (Baker et al. 1980). Present study was undertaken to (i) find out the association of the fungi with groundnut (ii) determine the pathogenic potentiality of the fungi and (iii) evaluate antifungal potentiality of some botanicals in-vitro against most frequently isolated fungi from groundnut.

\section{Materials and Methods}

Collection of samples: During the period of December 2010 to May 2012, 18 varieties of groundnut plant were grown in field plot of Botanical garden, Curzon Hall, University of Dhaka. Samples were collected from Botanic Garden (Curzon Hall campus), University of Dhaka and BARI, Gazipur. Collected samples were examined and symptoms were recorded. After microscopic observation fungi were isolated from healthy and diseased samples following the Blotter" and "Tissue planting" method on PDA medium (CAB 1968). Specimens were preserved in the Herbarium of Mycology and Plant Pathology laboratory, Department of Botany, University of Dhaka. The varieties used in the experiment were: GN, BB- 8, DG- 2, B- 5, B- 6, B- 7, BN- 1, BN- 2, BN- 3, BN- 4, DHAKA- 1, BARI- 5, BARI- 6, BARI- 7, BARI- 8, BARI- 9, $\mathrm{GN}_{1}$ and $\mathrm{GN}_{2}$. Isolated fungi were tested for their pathogenic potentiality. In the present investigation 48 species of fungi were isolated from groundnut and identified following Standard Literature (Booth 1971, Ellis 1971, 1976, Sutton 1980, Ellis and Ellis 1997, Barnett and Hunter 2000). Isolated fungi were tested for their pathogenic potentiality following modified "detached leaf technique" (Azad and Shamsi 2011). Cercospora arachidicola S. Hora, Pheoisariopsis personata Berk and M.A., Puccinia arachidis Speg. and Sclerotium rolfsii are well documented pathogens of groundnut. In this experiment five fungi namely $C$. acutatum Simmonds, C. dematium (Pers. Ex. Fr.) Grove., C. dematium orbiculare (Berk. \& Mont.) Arx., Colletotrichum $\mathrm{sp}_{._{1}}$ and Fusarium semitectum Berk. \& Rav. were found to be pathogenic to groundnut. Efficacy of five plant extracts namely Allium cepa L., A. sativum L., Azadiracta indica L., Tagetes patula L. and Zingiber officinale L. was evaluated against these five pathogenic fungi following poison food techniques (Grove and Moore 1962).

Preparation of plant extracts: The desired parts of each plant were thoroughly washed in tap water, air dried and then used for fresh extract preparation (Table 1). In case of leaves and bulbs, extracts were prepared by crushing known weight of fresh materials with distilled water in ratio of $1: 1(\mathrm{w} / \mathrm{v})$. The pulverized mass of a plant part was 
squeezed through four folds of fine cloth and the extracts were centrifuged at $3000 \mathrm{rpm}$ for 20 minutes to remove particulate matter. The supernatants were filtered through Whitman filter paper and the filtrate was collected in $250 \mathrm{ml}$ Erlenmeyer flasks. In this method, the requisite amount of the filtrate of each plant extract was mixed with PDA medium and sterilized in an autoclave at $121^{\circ} \mathrm{C}$ for 15 minutes.

Table 1. The particulars of plant extracts used in this experiments.

\begin{tabular}{llll}
\hline Plant species & Native name & Family & Plant part used \\
\hline Allium cepa & Onion & Liliaceae & Bulb \\
Allium sativum & Garlic & Liliaceae & Bulb \\
Azadiracta indica & Neem & Meliaceae & Leaf \\
Tagetes patula & Marigold & Asteraceae & Leaf \\
Zingiber officinale & Ginger & Zingiberaceae & Rhizome \\
\hline
\end{tabular}

The medium thus prepared was poured into sterilized Petri plates and was allowed to solidify. Each Petri plates was inoculated centrally with a $5 \mathrm{~mm}$ agar disc cut from the margin of actively growing culture of the test pathogen. In control set, a Petri plate containing PDA medium with the requisite amount of distilled water instead of a plant extract was also inoculated with agar disc of the test pathogen in the same way as described above. Three replications were maintained for both treatment and control sets. The inoculated Petri plates were incubated at $25 \pm 1{ }^{\circ} \mathrm{C}$. The radial growth of the colonies was measured after 5 days of incubation.

The percentage growth inhibition of each test pathogen was calculated by using the following formula

$$
I=\frac{C-T}{C} \times 100
$$

Where, $\mathrm{I}=$ percent growth inhibition, $\mathrm{C}=$ growth in control and $\mathrm{T}=$ growth in treatment

\section{Results and Discussion}

Use of plant extracts against plant pathogenic fungi and plant diseases is relatively a recent approach. Five fungi, isolated from leaflets of groundnut showing anthracnose, Colletotrichum leaf spot and rotting symptom were found to be pathogenic to the plant. This is the first report of anthracnose, Colletotrichum leaf spots caused by Colletotrichum spp. from Bangladesh. The isolated fungi were Colletotrichum acutatum, C. dematium, C. orbiculare, Colletotrichum sp. and Fusarium semitectum. Efficacy of five plant extracts namely Allium cepa, A. sativum, Azadiracta indica, Tagetes patula and Zingiber officinale was evaluated against those five fungi. The extent of inhibition, however, varied among the fungi.

The vegetative growth of $C$. acutatum showed highest (69\%) inhibition with T. patula at $20 \%$ followed by 53 and $46 \%$ inhibition at 10 and $5 \%$ concentration respectively. $Z$. officinale showed $36 \%$ inhibition of the fungus at highest concentration (20\%). Lowest 
inhibition of the fungus such as 20,14 and $11 \%$ was encountered at 20, 10 and $5 \%$ concentrations respectively (Fig. 1). This observations are in agreement with the observations made by Sing et al. (1997) and Mala et al. (1998).

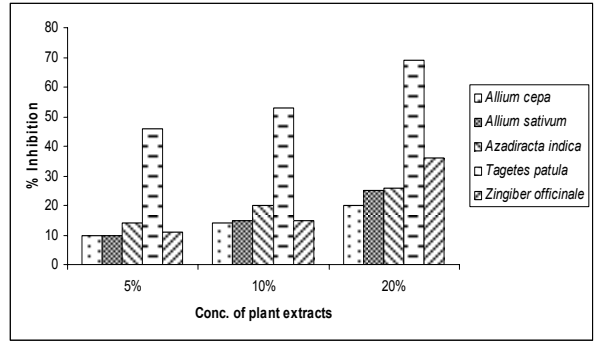

Fig.1. Effect of plant extracts on growth of Colletotrichum acutatum.

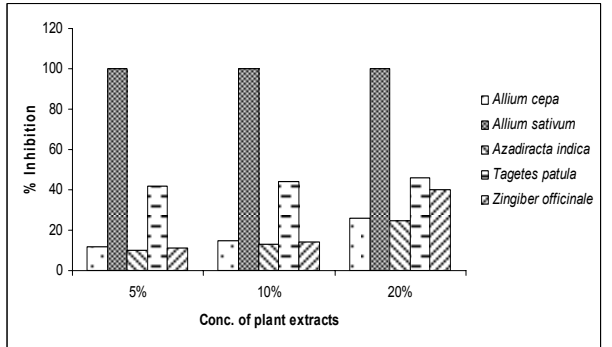

Fig. 2. Effect of plant extracts on growth of Colletotrichum dematium.

Colletotrichum dematium was completely checked with $A$. sativum at all the concentrations used ( 5,10 and $20 \%$ ). Less inhibition of the fungus was recorded when treated with 10,13 and $25 \%$ of $A$. indica at 5, 10 and $20 \%$ concentrations (Fig. 2). Higher fungitoxicity of A. sativum was also reported by Misra and Dixit (1976). Seed borne pathogens of jute were effectively controlled by Allium sativum (Ahmed and Sultana 1984). Shovan et.al. (2008) recorded $89.44 \%$ inhibition of C. dematium isolated from anthracnose of Soybean.

The growth of $C$. orbiculare was completely inhiteded by A. cepa, A. sativum and A. indica at all the concentrations used (5,10 and 20\%). Z. officinale and T. patula checked 45 and $34 \%$ colony growth of the fungus respectively at $20 \%$ concentration (Fig. 3 ).

Colonies of Colletotrichum sp. was $57 \%$ inhibited by Z. officinale at $20 \%$ concentration followed by $T$. patula, $51 \%$ inhibition of the colony at the same concentration. A. cepa and $A$. indica showed $39 \%$ inhibition of the fungus at $20 \%$ concentration. A. sativum inhibited 30, 36 and $45 \%$ colony growth of the fungus at 5, 10 and $20 \%$ concentrations respectively (Fig. 4).

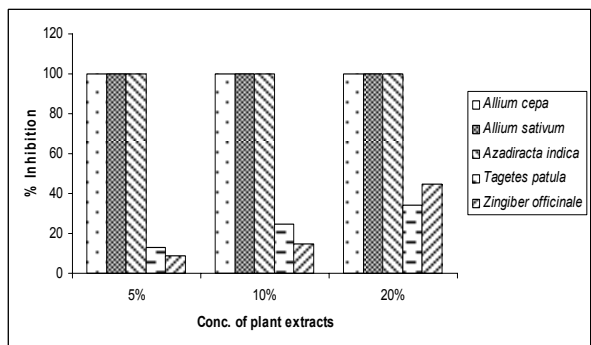

Fig. 3. Effect of plant extracts on growth of Colletotrichum orbiculare.

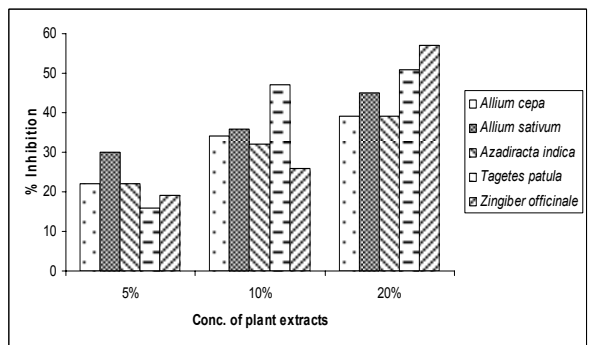

Fig. 4. Effect of plant extracts on growth of Colletotrichum $\mathrm{sp}$. 
Plant extract of $T$. patula inhibited $81 \%$ vegetative growth of Fusarium semitectum at 20 $\%$ concentration followed by 62 and $33 \%$ at 10 and $5 \%$ concentration respectively. $Z$. officinale checked 71, 61 and $42 \%$ colony growth of the fungus at 20, 10 and $5 \%$ concentrations respectively. A. sativum showed 62,44 and $38 \%$ inhibition of the fungal colony at the above mentioned concentrations. Allium cepa inhibited 53, 41 and $34 \%$ colony growth of the fungus at 20,10 and $5 \%$ concentrations respectively. $A$. indica showed lowest inhibition of the fungus 49.43 and $20 \%$ at 20, 10 and $5 \%$ concentrations. Methanol extract of $T$. patula inhibited growth of three pathogenic fungi Botrytis cineria, Fusarium moniliformae and Phythium ultimum ( Mares et al. 2004) (Fig. 5).

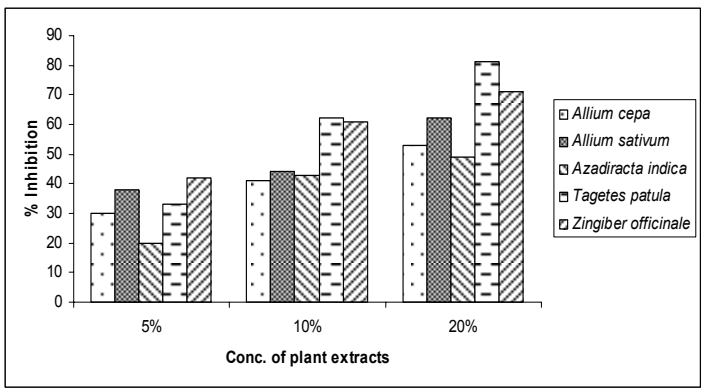

Fig. 5. Effect of plant extracts on growth of Fusarium semitectum.

In home and abroad, cultural practice and chemical control have been practiced against leaf spot, rust and stem rot diseases of groundnut, but this is the first approach of controlling the causal agents of anthracnose, Colletotrichum leaf spot and leaf rot of groundnut with botanicals in vitro .

Allium sativum completely inhibited the growth of $C$. dematium at all the concentration used ( 5, 10 and $20 \%$ ). Allium cepa, A. sativum and A. indica completely inhibited the growth of $C$. orbiculare at the same concentration used (5, 10 and 20\%). T. patula and $Z$. officinale also showed appreciable inhibition in colony growth of five species of fungi at 10 and $20 \%$ concentrations. Among the five plant extracts used A. cepa, A. sativum and $A$. indica showed excellent results in controlling the redial diameter of the colonies of $C$. orbiculare at $5 \%$ concentration. In addition to $C$. orbiculare, A. sativum also exhibited complete inhibition of $C$. dematium at the same concentration. Hadian (2012) reported that Allium sativum and A. indica at $100 \%$ concentrations inhibited growth of Fusarium oxysporum f. sp. lycopersici and Rhizoctonia solani two pathogenic fungi causing wilting disease of tomato.

This is the first report of evaluation of plant extracts against Colletotrichum spp. and F. semitectum isolated from groundnut. The present findings on the antifungal activities of these plant extracts may, in future, open a new horizon in plant disease control. 


\section{References}

Ahmed, H.U. 1985. Disease problem of pulses and oilseeds crops in Bangladesh. Paper presented at the First National Plant Pathological Conference of Bangladesh Phytopathological society held on 13-14 April, 1985 at BARI, Gazipur. 18 p.

Ahmed, A. and K. Sultana. 1984. Fungi toxic effects of Garlic on treatment of jute seed. Bangladesh J. Bot. 13 (2): 130-136.

Ambang, Z., B. Ndongo, G. Essono, J.P. Ngoh, P Kosma, G.M. Chewachong and A. Sganga. 2011. Control of leaf spot disease caused by Cercospora sp. on groundnut (Arachis hypogeae) using methanolic extracts of yellow oleander (Thevatia peruviana). AJCS 5 (3):227-232.

Azad, R. and S. Shamsi. 2011. Identification and pathogenic potentiality of fungi associated with Huttuyania cordata Thunb. Bangladesh J. Plant. Pathol. 20 (2):131-138.

Baker, M.A., K. B. Alam and M. J. Talukder. 1980. Occurrence of Groundnut rust in Bangladesh. Proc. $4^{\text {th }}$ and $5^{\text {th }}$ Annual Bangladesh Science Conference. Sec. 1.18 p.

Bakr, M. A., M. D. Hossain and M. M. Karim. 2009. Gradient of oil seed disease management, fungal associations and mycotoxin contamination. Advance in Oilseed Research in Bangladesh. BARI. 95- 108 pp.

Barnett, H. L. and B. Hunter. 2000. Illustrated Genera of Imperfect Fungi. 4th edn., Freedom Palestine. $218 \mathrm{pp}$.

BBS, 2007. Statistical year book of Bangladesh, Bangladesh Bureau of statistics. 182 pp.

Booth, C. 1971. The Genus Fusarium. The Commonwealth Mycological Institute. England. 273 pp.

CAB (Commonwealth Agricultural Bureau) 1968. Plant Pathologist's Pocket Book. The Commonwealth Mycological Institute, England 267 pp.

Ellis, M. B. 1971. Dematiaceous hyphomycetes. Commonwealth Mycological Institute, England. $507 \mathrm{pp}$.

Ellis, M.B. 1976, More Dematiaceous hyphomycetes. Commonwealth Mycological Institute, England. $608 \mathrm{pp}$.

Ellis, M. B. and J. P. Ellis. 1997. Micro fungi on Landplants. An Identification Handbook. Richmond Publishing Co. Ltd. 868 pp..

Fakir, G.A. 1980. An annotated list of seed borne diseases in Bangladesh. Agricultural Information Service, Dhaka. 17 p.

Grove, R.K and J. D. Moore.1962. Toximetric studies of fungicides against brown rot organism Sclerotina fruticola. Phytopathology. 52:876-880.

Hadian, S. 2012. Antifungal activity of some plant extracts against some plant pathogenic fungi in Iran. Asian J. Exp. Biol. Sci. 3 (4):714-718.

Mala, S. R., M. Radha, G. Revathy, and A.R. Rolyappan, A.R. 1998. Garlic as a biocide for Colletotrichum falcatum. Indian Journal of Plant Protection 26:49-51.

Mares, D, B. Tosi, F. Poli, E. Andreotti and C. Romagnoli. 2004. Antifungal activity of Tagetes patula extracts on some pathogenic fungi: ultra structure evidence on Pythium ultimum. Microbiological Research. 159 (3):295-304.

Mia, M.A.T.,M.M.E. Rahman, M. S. Mian and N.N. Tonu.2007. Research on fungal seed Pathology of six groups of crops in Bangladesh, A Review. Advances in Plant Pathological Research in Bangladesh. Plant Pathology Divisin. BARI. Pp. 177-208.

Misra, S.B. and S.N. Dixit. 1976. Fungicidal sectrum of the leaf extract of Allium sativum. Indian Phytopathol. 19 (4): 208-213.

Shamsi, S. and S. Sharmin. 2012. Fungal diseases of Groundnut from Bangladesh. Lambert Publishers. Germany. 54 pp.

Sharmin, S. 2012. Phylloplane mycoflora of groundnut (Arachis hypogeae L.) and its in vitro control with botanicals. M.S. thesis. Department of Botany, university of Dhaka, Bangladesh. i + viii $+88+78$ pp. 
Shovan, 1. R, M.K.A Bhuiyan, J.A. Begum and Z. Pervez . 2008. In vitro control of Colletotrichum dematium causing anthracnose of soybean by fungicides, plant extracts and Trichoderma herzinium. Int. J. Sustain. Crop Prod. 3 (3):10-17.

Sing, S. N., B.P..Yadav, S.K. Sinha and K.L. Ojha. 1997. Efficacy of plant extract in Inhibition of radial growth and spore germination of Colletotrichum capsici. Journal of Applied Biology. 7:58-61.

Sunker, G., S. Kulkaris, V.I. Benargi. 2005. Effectiveness of neem seed kernel extract in combination with selected fungicides for groundnut rust management. Int. Arach. Newsletter. 25: 34-41.

Sutton, B. C. 1980. The Coelomycetes, Fungi Imperfect with pycnidia, Acervuli and stroma, Commonwealth Mycological Institute. Kew Surrey, England, 525-537pp.

Talukder, M.J. 1974. Plant diseases in Bangladesh. Bangladesh J. Agric Res. 1 (1): 61-86.

Varnell, R. J and D. E. Mccloud. 1975. Germplasm preservation and genotype evaluation in Arachis Internal peanut program, Gainesvilla, Florida. 29 pp.

Weiss, E.A. 1983. Oilseed crops. Longman group limited, New York. USA. 7p.

Wikipedia, the free encyclopedia. 2012. List of fungi on Groundnut. 